\title{
POC-Scale Testing of Oil Agglomeration Techniques and Equipment for Fine Coal Processing
}

\author{
Topical Report \\ May 1 - June 30, 1997
}

RECEIVED

NOV 231998

OSTI

Work Performed Under Contract No.: DE-AC22-95PC95152

\author{
For \\ U.S. Department of Energy \\ Office of Fossil Energy \\ Federal Energy Technology Center \\ P.O. Box 880 \\ Morgantown, West Virginia 26507-0880
}

By

Alberta Research Council

Environmental Technologies

250 Karl Clark Road

Edmonton, Alberta

Canada T6N 1E4 


\section{Disclaimer}

This report was prepared as an account of work sponsored by an agency of the United States Government. Neither the United States Government nor any agency thereof, nor any of their employees, makes any warranty, express or implied, or assumes any legal liability or responsibility for the accuracy, completeness, or usefulness of any information, apparatus, product, or process disclosed, or represents that its use would not infringe privately owed rights. Reference herein to any specific commercial product, process, or service by trade name, trademark, manufacturer, or otherwise does not necessarily constitute or imply its endorsement, recommendation, or favoring by the United States Government or any agency thereof. The views and opinions of authors expressed herein do not necessarily state or reflect those of the United States Government or any agency thereof. 


\section{DISCLAIMER}

Portions of this document may be illegible in electronic image products. Images are produced from the best available original document. 


\section{Table of Contents}

\section{-. Page}

$1.0 \quad$ Project Management Plan ..........................................................................

2.0 Summary of the Work Completed and in Progress.................................... 1

2.1 Project Planning and Management (Task 1) ..................................... 1

2.2 Host Site Selection/Environmental Questionnaire (Subtask 2.1)..... 2

2.3 Coal Selection and Characterization Plan (Subtask 2.2)................... 2

2.4 Laboratory (Batch) Test Plan (Subtask 2.3) and Continuous Bench-Scale Test Plan (Subtask 2.4) .................................................. 2

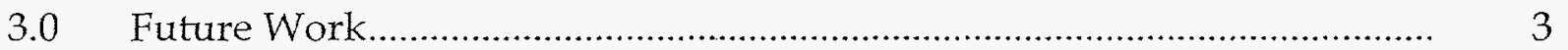




\subsection{Introduction}

This report covers the technical progress achieved from May 01, 1997 - June 30, 1997, on the POC-Scale Testing Oil Agglomeration Techniques and Equipment for Fine Coal Processing, under PETC/DOE Contract No. DE-AC22-95PC95152.

The objective of this project is to develop and demonstrate a Proof-of-Concept (POC) scale oil agglomeration technology capable of increasing the recovery and improving the quality of fine coal streams. Two distinct agglomeration devices will be tested, namely, a conventional high shear mixer and a jet processor.

To meet the overall objective an 11 task work plan has been designed. The work ranges from batch and continuous bench-scale testing through the design, commissioning and field testing of POC-scale agglomeration equipment.

The project commenced on June 14, 1995 and was suspended on June 01, 1996 due to the lack of host site for POC equipment demonstration. On April 14, 1997 ARC has signed Host Agreement with Drummond Company Inc. and project was resumed on May 01, 1997.

During the reporting period there were activities under the following tasks:

- Task 1 - Project Planning and Management

- Task 2 - Host Site Selection and Plan Formulation

The work on the remaining tasks is scheduled for the next months.

\subsection{Summary of Work completed and in Progress}

\subsection{Project Planning and Management (Task 1)}

Following DOE's Contract Office request, Contractor prepared revision of:

- Project Management Plan

- Cost Plan

- Labour Plan

- Milestone Plan, and

- Statement of Work 
All above documents were submitted to DOE for revision and approval.

\subsection{Host Site Selection/Environmental Questionnaire (Subtask 2.1)}

Host site has been already selected. Drummond's Shoal Creek Mine Preparation Plant was designated as a host site for POC equipment demonstration.

The Drummond Company Inc. owns 13 mines and operates five coal preparation plants. All company mines are located on Warrior Coal Field. The remaining identified coal resources on this field are estimated at about 20,000 million short tons. The total reserves held by Drummond are estimated at 400,000,000 tons.

Coal procurement plan was prepared in the first phase of the project and will be revised to reflect new project host site, Shoal Creek Mine Preparation Plant.

Environmental Questionnaire was sent to Drummond and after receiving executed copy, it will be sent to DOE.

\subsection{Coal Selection and Characterization Plan (Subtask 2.2)}

Drummond Company Inc. will submitt the following samples for batch (scale) testing:

- Floatation feed $600 \mu \mathrm{m} \times 250 \mu \mathrm{m}$ ( 28 mesh $\times 60$ mesh) from its Shoal Creek Mine Preparation Plant

- Cyclone overflow $250 \mu \mathrm{m} \times 0(60$ mesh $\times 0)$ that is a feed for flotation at the same plant

- Two coal fines from the existing ponds (location to be identified)

Coal Characterization Plan that was developed in the first phase of the project was revised in order to accommodate new project coal fines.

2.4 Laboratory (Batch) Test Plan (Subtask 2.3) and Continuous Bench-Scale Test Plan (Subtask 2.4).

Both plans were developed in the first phase of the project and after revision would be used for testing Drummond's coal fines. 
3.0 Future Work

Future work to be performed and/or completed in the next reporting period is as follows:

- commence coal characterization

- commence batch scale testing

- select and bring to Devon laboratories a bulk sample of coal fines for continuous bench scale testing 